\title{
Altered esophageal motility during perception of bolus transit in healthy volunteers
}

\author{
Tarciana Vieira COSTA and Roberto Oliveira DANTAS
}

Received 5/7/2019

Accepted 30/9/2019

\begin{abstract}
Background - The perception of bolus transit through the thoracic esophagus may be caused by altered esophageal anatomy and function. Objective - To evaluate the hypothesis that, in healthy volunteers, swallows followed by perception of esophageal bolus transit are associated with changes in esophageal motility. Methods - Simultaneous evaluation of motility and perception of esophageal bolus transit was performed in 22 healthy volunteers. Esophageal motility was evaluated by high-resolution manometry with a 32-channel solid state catheter. Each volunteer performed, in the sitting position, 10 swallows of a $5 \mathrm{~mL}$ bolus of saline and 10 swallows of pieces of $1 \mathrm{~cm}^{3}$ of bread, with an interval of at least 30 seconds between swallows. After each swallow the volunteers were asked about the perception of bolus transit through the esophagus. Results - Perception of bolus transit occurred in $11.7 \%$ of liquid swallows and in $48.1 \%$ of solid swallows. In liquid swallows the perception was associated with higher distal contractile integral and shorter proximal contraction length. Perception of solid bolus transit was associated with a longer distal latency, longer proximal contraction length, lower proximal contractile integral and shorter proximal contraction duration. Conclusion - The perception of swallowed bolus transit through the esophagus in healthy individuals is more frequent with solid than liquid swallows and is associated with changes in proximal esophageal contractions.
\end{abstract}

HEADINGS - Esophageal motility disorders. Deglutition disorders. Smooth muscle. Dysphagia.

\section{INTRODUCTION}

Dysphagia is a symptom of difficulty in swallowing, which can be related to a dysfunction in the oral, pharyngeal or esophageal phase of swallowing ${ }^{(1)}$. The perception of bolus transit through the thoracic esophagus may be caused by esophageal anatomic changes, motility disorders, esophageal hypersensitivity or hiper vigilance $^{(1)}$, or the dysphagia is functional. Functional dysphagia is defined as "a sensation of abnormal bolus transit through the esophageal body in the absence of structural, mucosal, or motor abnormalities to explain the symptom"(2). Functional dysphagia is the least prevalent of the functional esophageal disorders ${ }^{(2)}$. Esophageal motility disorders can cause mild-to-severe dysphagia ${ }^{(3,4)}$.

Healthy individuals may have, in some swallows, the perception of esophageal bolus transit. This sensation may be a manifestation of functional dysphagia, which has a different prevalence in different populations, $7.5 \%$ of the functional esophageal diseases in the United States ${ }^{(5)}$ and $0.6 \%$ in Asia ${ }^{(6)}$. These differences are related to different populations and diagnostic criteria. However, the perception of bolus transit in some swallows in healthy individuals is not always a consequence of functional dysphagia, but rather, of an altered esophageal motility. Previous studies did not show changes in esophageal motility in perceived bolus transit ${ }^{(7)}$, perhaps because the method used for assessment of esophageal motility was different from the ones currently used, the high-resolution manometry (HRM). The hypothesis of this investigation was that perception of bolus transit through the esophagus after swallows is associated with changes in esophageal motility.

To evaluate this hypothesis esophageal motility was investigated by high- resolution manometry, and swallows followed by the perception of bolus passage through the esophagus were compared with those without perception.

\section{METHODS}

Esophageal motility and perception of esophageal transit was evaluated in 22 healthy volunteers, 10 men and 12 women with ages from 22 to 50 years (mean: $38.1 \pm 7.7$ years). The mean of body mass index was $29.1 \pm 3.7 \mathrm{~kg} / \mathrm{m}^{2}$. They did not have any gastroenterologi$\mathrm{cal}$, neurological, endocrine disease, surgery in the digestive tract or any disease at the time of evaluation of esophageal motility. They did not complain of dysphagia, heartburn, acid regurgitation or chest pain. The investigation was approved by the Human Research Ethics Committee of the University Hospital, number 14757/2012, and all volunteers gave written informed consent to participate in the investigation.

Esophageal motility was evaluated by high resolution manometry with a 32-channel solid state catheter (Sandhill Instruments, Highlands Ranch, CO, USA). The tests were performed after a 6-hour fasting, with individuals in sitting position. After the calibration at $0 \mathrm{mmHg}$ and $100 \mathrm{mmHg}$, the manometry catheter was introduced through the nose until the distal channels reached the stomach, and registration of intraluminal pressure from the pharynx to the stomach was performed.

After five minutes for stabilization of the manometric record, each volunteer performed, in the sitting position, 10 swallows of a $5 \mathrm{~mL}$ bolus of saline at room temperature. After five minutes from the end of the wet swallows the volunteers performed another 10 
swallows of $1 \mathrm{~cm}^{3}$ pieces of bread, with an interval of at least 30 seconds between swallows. After each swallow the volunteers were asked about the perception of bolus transit through the esophagus, using the classification described by Lazarescu et al. ${ }^{(7)}$ : grade 1- none; grade 2- slow passage; grade 3- stepwise; grade 4- partial passage; grade 5- obstruction. Therefore, swallows classified as grade 1 were considered without perception of bolus passage through the esophagus, and swallows classified as grades 2-5 were considered with perception.

Each swallow was analyzed for the integrated relaxation pressure (IRP) of the lower esophageal sphincter, the contraction front velocity $(\mathrm{CFV})$, distal contraction integral (DCI), distal latency (DL), proximal contraction length (PCL), proximal contraction integral (PCI), proximal contraction duration (PCD), and maximal upper esophageal sphincter (UES) pressure. The method for the measurement of each variable was previously described ${ }^{(8,9)}$. Ineffective contractions were defined as failed (DCI $<100 \mathrm{mmHg} . \mathrm{s.cm}$ ) or weak (DCI $>100 \mathrm{mmHg}$.s.cm but $<450 \mathrm{mmHg}$.s.cm) by the Chicago classification v3. $0^{(10)}$. Proximal esophageal contractions were defined as contractions proximal to peristaltic break (transition zone) and distal contractions as contractions distal to peristaltic break $^{(11)}$ (FIGURE 1). The reference for PCI and DCI was the isobaric contour of $30 \mathrm{mmHg}$.

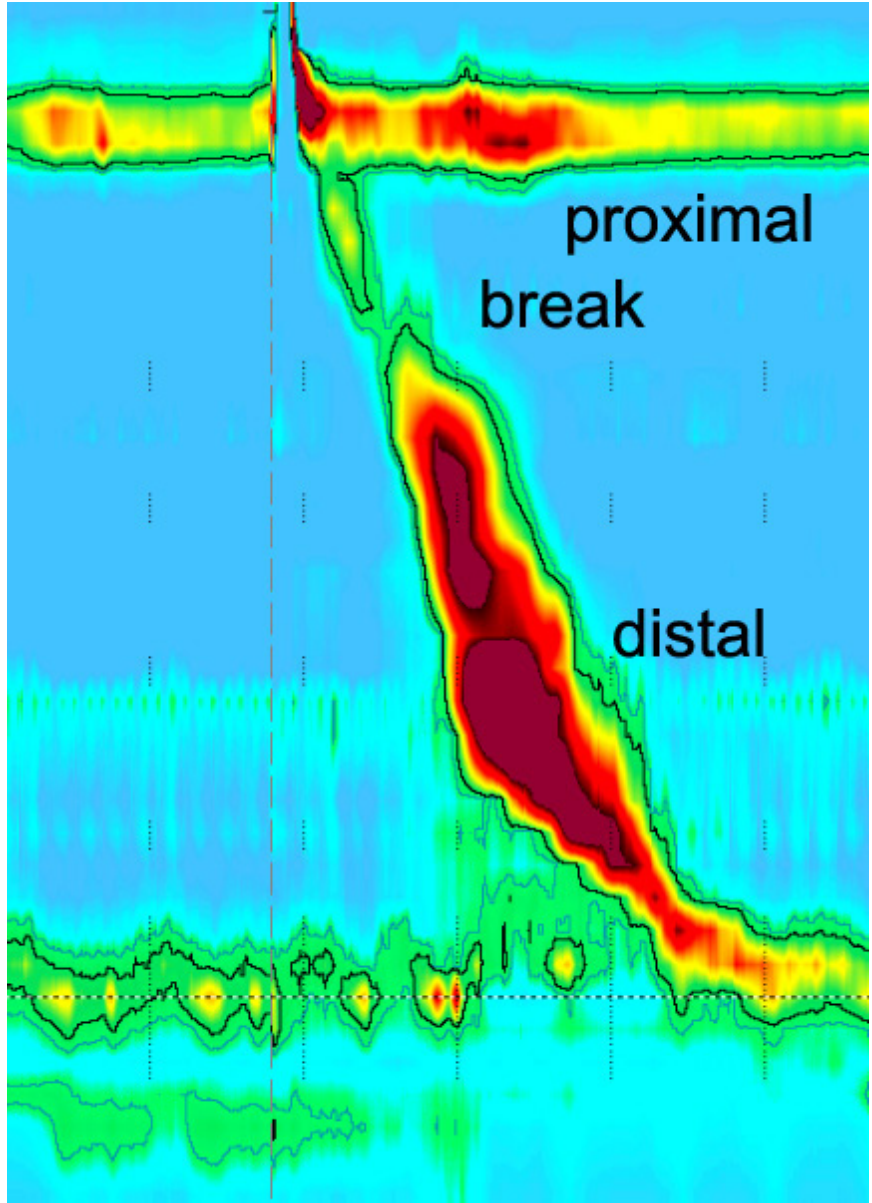

FIGURE 1. Peristaltic contraction of a volunteer after liquid swallow. Proximal esophageal contraction is above the peristaltic break (transition zone), and distal esophageal contraction is below the peristaltic break.
Statistical analysis of manometry results of the swallows followed or not by perception of bolus passage through the esophagus was done by multivariate analysis of variance (MANOVA). The results are shown as mean and standard deviation (SD). A $P \leq 0.05$ was considered significant.

\section{RESULTS}

The percentage of swallows followed by perception of esophageal transit of liquid and solid bolus is described in TABLE 1. The proportion of swallows followed by perception was higher with solid bolus (48.1\%) compared with liquid swallows $(11.7 \%$, $P<0.050)$. Ineffective contractions with liquid bolus was $24.8 \%$, and with solid bolus $43.4 \%(P<0.050)$.

TABLE 1. Percentage of liquid and solid swallows followed by perception of esophageal transit and percentage of ineffective contraction after liquid and solid swallows.

\begin{tabular}{ll}
\hline Perception after liquid swallows & $11.7 \%$ \\
Perception after solid swallows & $48.1 \%$ \\
Ineffective contraction after liquid swallows & $24.8 \%$ \\
Ineffective contraction after solid swallows & $43.4 \%$ \\
\hline
\end{tabular}

Liquid swallows followed by perception of bolus passage through the esophagus were associated with higher DCI (2257.1 $\mathrm{mmHg.s.cm})$ and shorter PCL $(3.8 \mathrm{~cm})$ compared with swallows without perception (DCI: $1187.0 \mathrm{mmHg} . \mathrm{s} . \mathrm{cm}, P=0.001$, andPCL:4.7 cm, $P=0.005$ ) (TABLE 2).

TABLE 2. Esophageal motility in healthy volunteers with and without perception of bolus transit through the esophagus after swallows of liquid bolus. Mean (SD).

\begin{tabular}{lccc}
\hline & No perception & Perception & $P$ value \\
\hline IRP $(\mathrm{mmHg})$ & $6.9(0.4)$ & $9.3(1.3)$ & 0.079 \\
CFV $(\mathrm{cm} / \mathrm{s})$ & $4.8(0.2)$ & $5.4(0.8)$ & 0.485 \\
DCI (mmHg.s.cm) & $1187.0(87.2)$ & $2257.1(308.2)$ & $0.001 *$ \\
DL (s) & $6.6(0.1)$ & $6.8(0.3)$ & 0.529 \\
PCL (cm) & $4.7(1.4)$ & $3.8(1.2)$ & $0.005 *$ \\
PCI (mmHg.s.cm) & $295.0(251.3)$ & $263.2(193.9)$ & 0.551 \\
PCD (s) & $2.4(1.0)$ & $2.3(0.6)$ & 0.586 \\
Maximal UES & $468.5(112.0)$ & $467.0(87.8)$ & 0.948 \\
pressure $(\mathrm{mmHg})$ & & & \\
\hline
\end{tabular}

IRP: integrated relaxation pressure; CFV: contraction front velocity; DCI: distal contractile integral; DL: distal latency; PCL: proximal contraction length; PCI: proximal contraction integral; PCD: proximal contraction duration; UES: upper esophageal sphincter. $* P<0.050$ perception vs no perception.

Perception of solid bolus transit was associated with a longer DL (no perception: $6.4 \mathrm{~s}$, perception: $7.1 \mathrm{~s}, P=0.016$ ), longer PCL (no perception: $4.2 \mathrm{~cm}$, perception: $6.6 \mathrm{~cm}, P=0.001$ ), lower PCI (no perception: $333.3 \mathrm{mmHg}$.s.cm, perception: $228.7 \mathrm{mmHg} . \mathrm{s.cm}$, $P=0.002$ ) and shorter PCD (no perception: 2.5 s, perception: 1.9 s, $P=001$ ) (TABLE 3). 
TABLE 3. Esophageal motility in healthy volunteers with and without perception of bolus transit through the esophagus after swallows of solid bolus. Mean (SD).

\begin{tabular}{lccc}
\hline & No perception & Perception & $P$ value \\
\hline IRP (mmHg) & $7.6(4.6)$ & $7.9(4.9)$ & 0.734 \\
CFV (cm/s) & $4.6(2.1)$ & $4.7(2.8)$ & 0.830 \\
DCI (mmHg.s.cm) & $1129.1(1049.9)$ & $1239.0(1137.8)$ & 0.604 \\
DL (s) & $6.4(1.2)$ & $7.1(2.0)$ & $0.016^{*}$ \\
PCL (cm) & $4.2(1.3)$ & $6.6(1.3)$ & $0.001^{*}$ \\
PCI (mmHg.s.cm) & $333.3(229.4)$ & $228.7(223.1)$ & $0.002^{*}$ \\
PCD (s) & $2.5(0.9)$ & $1.9(0.8)$ & $0.001 *$ \\
$\begin{array}{l}\text { Maximal UES } \\
\text { pressure (mmHg) }\end{array}$ & $492.9(120.1)$ & $464.5(100.1)$ & 0.086 \\
\hline
\end{tabular}

IRP: integrated relaxation pressure; CFV: contraction front velocity; DCI: distal contraction integral; DL: distal latency; PCL: proximal contraction length; PCI: proximal contraction integral; PCD: proximal contraction duration; UES: upper esophageal sphincter. $* P<0.050$ perception vs no perception.

\section{DISCUSSION}

Our results showed that the perception of esophageal bolus transit was associated with changes in esophageal motility, mainly with alteration in proximal esophagus.

In humans the cervical esophagus is composed of striated muscles; contractions are centrally mediated and occur in response to sequential activation of the motor neurons in the nucleus ambiguous. The smooth muscle of the distal esophagus is innervated by intramural inhibitory and excitatory neurons ${ }^{(12)}$. The proximal few centimeters of the esophagus contains receptors and afferent innervations that are sensitive to mucosal stimulation ${ }^{(13)}$.

The observed changes in esophageal motility associated with perception were more related to the proximal than the distal esophagus, mainly in the solid swallows, when there was increase in PCL, decrease in PCI, decrease in PCD and decrease in PCI. Also, there was a decrease in PCL with liquid swallows. Receptors sensitive to mucosal stimulation found in the proximal esophageal mucosa may mediate the afferent feedback that activates esophageal peristalsis during swallowing ${ }^{(13)}$. The swallowing systems may have variation in the response to stimuli between individuals. However, in healthy volunteers successive swallows of the same stimuli, performed with enough interval, caused similar response in amplitude, duration and velocity of esophageal contractions in a previous report ${ }^{(14)}$, which was not performed with high-resolution manometry.

A previous investigation described that there is no agreement between objective measurements of esophageal function and subjective perception of bolus transit, suggesting that an increase in bolus transit perception in patients without mechanical obstruction might be due to esophageal hypersensitivity ${ }^{(7)}$. Anxiety is a predictor of perception of esophageal bolus transit in cases of hypotensive motility ${ }^{(15)}$. Esophageal motor function alone did not explain differences in bolus perception, suggesting that different mechanisms are relevant in different individuals. The perception of bolus transit is less common than abnormal motility ${ }^{(15)}$. In a previous investigation only $9.6 \%$ of the volunteers reported perception of esophageal bolus passage, which happened in $3.5 \%$ of the swallows ${ }^{(15)}$. The difference to our results may be due to the different method to assess perception and characteristics of the population. Perception depend on sociocultural, psychological, biological and ethnic variables ${ }^{(16)}$. In addition, older studies did not used high-resolution manometry as the method for esophageal motility evaluation $^{(7,17)}$, and then the proximal esophageal area was not well defined; however, in one of them the amplitude of contraction measured at $15 \mathrm{~cm}$ from the lower esophageal sphincter was lower in patients with perception of solid bolus transit than inpatients without perception ${ }^{(17)}$.

The perception of solid bolus swallows may be caused by inadequate adaptation of esophageal contraction to the bolus ${ }^{(17)}$. Solid swallows increases the amplitude of contraction in proximal esophagus and the peristaltic duration throughout the esophagus, when compared with liquid swallows ${ }^{(18)}$. The results of this investigation found that the DCI increased in liquid swallows followed by perception, but did not change in solid swallows. The perception was not consequence of ineffective contractions once the DCI did not decrease in perceived swallows. The PCI with liquid bolus was similar between contraction with perception and without perception, but with solid bolus PCI decrease in contraction with perception. Adaptations of proximal and distal contraction to bolus characteristics may have a significant role in the perception of esophageal transit.

The investigation has some limitations. Esophageal manometry was performed only in the sitting position, and assessment of radiologic esophageal transit was not performed.

\section{CONCLUSION}

The perception of bolus passage through the thoracic esophagus was more frequent in solid than liquid swallows, and was associated with changes in proximal esophageal contractions.

\section{Authors' contribution}

Tarciana V Costa had participation in study planning, investigation, data collection and discussion of results, in addition to manuscript preparation and in decision to submit to publication. Roberto O Dantas had participation in study planning, discussion of results, in manuscript preparation and subsequent decision to submit to publication.

\section{Orcid}

Roberto Oliveira Dantas: 0000-0003-2183-0815.

Tarciana Vieira Costa: 0000-0003-1382-6883. 
Costa TV, Dantas RO. Alteração da motilidade do esôfago durante percepção do trânsito do bolo em voluntários saudáveis. Arq Gastroenterol. 2019;56(4):386-9.

RESUMO - Contexto - A percepção do trânsito de bolo deglutido através do esôfago torácico pode ser consequência de alterações anatômicas ou funcionais do esôfago. Objetivo - Avaliar, em voluntários saudáveis, se a deglutição com percepção do trânsito do bolo pelo esôfago está associada a alteração da motilidade esofágica. Método - Avaliação simultânea da percepção do trânsito pelo esôfago e motilidade foi realizada em 22 voluntários saudáveis. A motilidade esofágica foi avaliada por manometria de alta resolução. Cada voluntário realizou, na posição sentada, 10 deglutições de $5 \mathrm{~mL}$ de soro fisiológico e 10 deglutições de pedaços de $1 \mathrm{~cm}^{3}$ de pão, com um intervalo de pelo menos 30 segundos entre as deglutições. Após cada deglutição, os voluntários foram questionados sobre a percepção do trânsito do bolo através do esôfago. Resultados - A percepção do trânsito ocorreu em $11,7 \%$ das deglutições do bolo líquido e em $48,1 \%$ das deglutições do bolo sólido. A percepção do bolo líquido foi associada com menor extensão de contração proximal e maior integral da contração distal, comparadas com deglutições sem percepção. A percepção do trânsito de bolus sólido foi associada a maior latência distal, menor extensão de contração proximal, menor integral da contração proximal e menor duração da contração proximal. Conclusão - A percepção do trânsito do bolo deglutido pelo esôfago torácico ocorreu mais frequentemente com bolo sólido e foi associada a alteração das contrações esofágicas proximais.

DESCRITORES - Transtornos da motilidade esofágica. Transtornos de deglutição. Músculo liso.

\section{REFERENCES}

1. Clavé P, Shaker R. Dysphagia: current reality and scope of the problem. Nat Rev Gastroenterol Hepatol. 2015;12:259-70.

2. Aziz Q, Fass R, Gyawali CP, Miwa H, Pandolfino JE, Zerbib F. Esophageal disorders. Gastroenterology. 2016;150:1368-79.

3. Rohof WOA, Bredenoord AJ. Chicago classification of esophageal motility disorders: lessons learned. Curr Gastroenterol Rep. 2017;19:37-42.

4. Wang D, Wang X, Yu Y, Xu X, Wand J, Jia Y, et al. Assessment of esophageal motor disorders using high-resolution manometry in esophageal dysphagia with normal endoscopy. J Neurogastroenterol Motil. 2019;25:61-7.

5. Drossman DA, Li Z, Andruzzi E, Temple RD, Talley NJ, Thompson WG, et al. US householder survey of functional gastrointestinal disorders. Prevalence, sociodemography, and health impact. Dig Dis Sci. 1993;38:1569-80.

6. Kwan ACP, Chakkaphak BS, Chang FI, Ke WY, Law NM, Leelakusolvong S, et al. Validation of Rome III criteria for functional gastrointestinal disorders by factor analysis of symptoms in Asian patient sample. J Gastroenterol Hepatol. 2003;18:796-802.

7. Lazarescu A, Karamanolis G, Aprile L, Oliveira RB, Dantas R, Sifrim D. Perception of dysphagia: lack of correlation with objective measurements of esophageal function. Neurogastroenterol Motil. 2010;22:1292-e337.

8. Herregods TVK, Roman S, Kahrilas PJ, Smout AJPM, Bredenoord AJ. Normative values in esophageal high-resolution manometry. Neurogastroenterol Motil. 2015;27:175-87.

9. Bredenoord AJ, Fox M, Kahrilas PJ, Pandolfino JE, Schwizer W, Smout AJP \& the International High Resolution Manometry Working Group. Chicago classification criteria of esophageal motility disorders defined in high resolution esophageal pressure topography. Neurogastroenterol Motil. 2012;24 (Suppl 1):57-65.
10. Kahrilas PJ, Bedenoord AJ, Fox M, Gyawali CP, Roman S, Smout AJPM, Pandolfino JE. The Chicago classification of esophageal motility disorders, V3.0. Neurogastroenterol Motil 2015;27:160-74

11. Pohl D, Ribosi M, Savarino E, Frühauf H, Fried M, Castell DO, Tutuian R. Characteristics of the esophageal low-pressure zone in healthy volunteers and patients with esophageal symptoms: assessment by high-resolution manometry. Am J Gastroenterol. 2008;103:2544-9.

12. Goyal RK, Chaudhury A. Physiology of normal esophageal motility. J Clin Gastroenterol. 2008;42:610-9.

13. Lang IM. Brain stem control of the phases of swallowing. Dysphagia. 2009;24:333-48

14. Dantas RO. Effect of successive swallows on oesophageal motility of normal volunteers, patients with Chagas' disease and patients with idiopathic achalasia. Neurogastroenterol Motil. 2003;15:57-62.

15. Cisternas D, Scheerens C, Omari T, Monrroy H, Hani A, Leguizano A, et al. Anxiety can significantly explain bolus perception in the context of hypotensive esophageal motility: results of a large multicenter study in asymptomatic individuals. Neurogatroenterol Motil. 2017;29:e13088.

16. Francisconi CF, Sperber AD, Fang X, Fukudo S, Gerson MJ, Kang JY, et al. Multicultural aspects in functional gastrointestinal disorders (FGIDs). Gastroenterology. 2016;150:1344-54.

17. Dalmazo J, Aprile LRO, Dantas RO. Esophageal contractions, bolus transit and perception of transit after swallows of liquid and solid bolus in normal subjects. Arq Gastroenterol. 2012;49:250-4.

18. Johnston BT, Colins JS, McFarland RJ, Blackwell JN, Love AH. A comparison of esophageal motility in response to bread swallows and water swallows. Am J Gastroenterol. 1993;88:351-5. 